\title{
THE DEGENTRALIZATION OF COLLECTIVE BARGAINING: A LITERATURE REVIEW AND COMPARATIVE ANALYSIS
}

\author{
HARRY C. KATZ*
}

\begin{abstract}
The author reviews evidence that the bargaining structure is becoming more decentralized in Sweden, Australia, the former West Germany, Italy, the United Kingdom, and the United States, although in somewhat different degrees and ways from country to country He then examines the various hypotheses that have been offered to explain this significant trend Shifts in bargaining power, as well as the diversification of corporate and worker interests, have played a part in this change, he concludes, but work reorgan1zation has been more influential still. He also explores how the roles of central unıons and corporate industrial relatıons staffs are challenged by bargainıng structure decentralization, and discusses the research gaps on this subject that need to be filled.
\end{abstract}

$\mathbf{R}$ eports have appeared since the early 1980 s suggesting that the locus of collective bargaining is shifting downward in a number of countries, often from a national or mult1-company level to the firm or plant level. This paper reviews evidence concerning recent decentralization in the structure of collective bargaining in six countries: Sweden, Australia, the former West Germany, Italy, the United Kingdom, and the United States. Those countries, for which there is a sizable literature on recent changes in the locus of collective bargaining, represent a wide range in the degree to which bargaining was centralized as of 1980 . At that time, collective bargaining in Sweden and Australia was extremely centralized; in Germany and

*The author, Professor at the New York State School of Industrial and Labor Relations (NYSSILR), Cornell Unıversity, thanks George Strauss, Peter Katzensteın, and participants at workshops held at the Sloan School of Management, MIT, and the NYSSILR for their many helpful suggestions
Italy, moderately centralized; and in the United Kingdom and the United States, relatively decentralized.

This review examines both the formal structure of bargaining, which applies to the employees covered by a collective bargaining agreement, and informal bargaining structures (such as pattern bargaining, whereby a lead settlement is followed closely in other negotiations). In addition, since many important industrial relations matters are settled through written or oral agreements that are not necessarily included in formal written contracts, I also consider changes in the locus and intensity of informal negotiations.

After reviewing the substantial evidence suggesting that bargaining structure is becoming more decentralized, I evaluate several hypotheses that have been offered to explain this development. Some of these hypotheses appear to be more credible than others in the light of a comparison of the experiences of the six countries. 


\section{The Complex Nature and Role of Bargaining Structure}

Bargaining structure has been recognized as influential because it affects the process of bargaining. We know that access to detailed information about the direct and indirect participants to a labor agreement is the precondition for understanding how bargaining occurs. The structure of bargaining also is important as it affects bargaining outcomes and the roles of unions and management. From Commons (1909) and Ulman (1955) on, it has been observed that unions often centralize bargainıng to strengthen their leverage at the bargaining table.

History also demonstrates, however, that although in many cases unions prefer centralized bargaining (to take working conditions out of competition) and employers prefer decentralized bargaining (to respond to local conditions and gain whipsaw advantage), the parties' preferences are not always so simply ordered. In some cases, for example, unions prefer firm-level over industry-level bargaining because the former gives them a power advantage. ${ }^{1}$ In some other cases, both large employers and their unions favor industrywide bargaining as a device through which they can "cartelize" the industry and drive out low-cost competition. ${ }^{2}$

We have also come to understand that bargaining structure both influences and is influenced by the distribution of bargaining power. Yet, data that allow clear tests of the effects of changes in bargaining structure on bargaining outcomes generally have not been avallable.

The difficulty of assessing the effects of bargaining structure arises in part from the fact that there is no simple measure of the degree of bargaining structure centralization, because the location of collective bargaining often differs depending on the subject of bargaining. In many countries, wages are negotiated in company or sectoral agree-

${ }^{1} \mathrm{US}$ automobile collective bargaining is an example of this bargaining structure (Katz 1985:29-38)

${ }^{2}$ In the post-World War Two period, bargaining in the U S inter-city trucking and coal industries followed this pattern (Williamson 1968) ments, and work rules are set at a lower level, often in plant agreements. Furthermore, worker participation in decision making often occurs at still another bargaining level, or through informal mechanisms (works councils or shop floor discussions, for example) rather than through collective bargaining agreements.

Still, as reported in this paper, it is possible to point to suggestive evidence concerning the effects of recent decentralization on bargaining outcomes. In addition, we know that bargaining structure exerts significant effects on the internal politics of unions. Recent research also examines how the roles of corporate industrial relations staffs are being altered by the movement toward more decentralized bargaining structures.

\section{Recent Changes in Bargaining Structure in Six Countries ${ }^{3}$}

\section{Sweden}

Sweden has long been viewed as the archetypical case of highly centralized bargaining, given the dominant role played by the national agreement negotiated between the employers' confederation (SAF) and the blue-collar union confederation (LO) (Swenson 1989). Beginning in 1956, the SAFLO agreement provided recommended wage increases, stipulations concerning non-wage issues, and often other detailed recommendations concerning employment conditions to the national affiliates of the LO and SAF The subsequent sectoral agreements often closely followed these recommendations, and company-level bargaining (and agreements) went on to supplement the sectoral agree-

\footnotetext{
${ }^{3}$ As briefly remarked above, I chose these six countries in part because they represent a wide spectrum in the degree of centrahization of their bargaining structure at the start of the period in question, and partly because of the avalability of much literature written in English in recent years on bargaining structure in these countries One referee suggested that this paper also analyze recent experience in Canada and Japan. In my vew, not much of interest has changed in recent years in Japan's bargaining structure, and developments in Canada do not differ significantly from the trends apparent in the six countries I examine
} 
ments. This relatively centralized bargaining resulted in moderate pay settlements and relatively low strike frequency (Swenson 1989). In addition, unions used the structure to implement their policy of wage solidarity (the negotiation of limited intra- and interindustry wage differentials), which was a key part of the "Swedish model."

After 1984, the dominance of the central agreement declined (EIRR 1992a). In 1984, industry-level bargaining completely replaced the SAF-LO agreement. In 1985 and 1986, there were SAF-LO agreements, but these agreements differed from those of past years in their treatment of non-wage issues, on which they included more recommendations and fewer stipulations. National wage bargaining was replaced again by industry-level bargaining in 1988. In 1991 there was a mediated national central two-year agreement that forbade local-level wage bargaining (EIRR 1991:28). A complete break with the traditional centralized SAF-LO agreement is likely in the future, because in February 1991 the SAF abruptly announced it would no longer take part in central negotiations and disbanded its wage bargaining staff.

There have also appeared numerous reports of increases in the intensity and depth of firm-level bargaining (Pontusson and Swenson 1992; EIRR 1992a). In a sharp break with the past, a number of these firm-level (or plant-level) agreements in recent years included profit sharing and other contingent pay mechanisms that linked worker pay increases to firm or worker performance or to worker skill level (Pontusson and Swenson 1992:21). As we shall see, the emergence of contingent pay is a frequent occurrence in all the countries reviewed in this paper.

The traditional Swedish bargaining structure included a substantial amount of firmand plant-level bargaining, which led to "wage drift" (Swenson 1989; Flanagan, Soskice, and Ulman 1983). Thus, it is not the presence of local bargaining that distinguishes recent experience. Rather, what is new is the absence of a central SAF-LO agreement in a number of recent years, employers' refusal to engage in further central bargaining, and the intensity and depth of local bargaining over non-wage issues.
In the 1980s, large employers that had previously supported centralized collective bargaining, particularly those in the engineering sector and their influential Engineering Employers' Association (which includes the auto manufacturers), favored a shift toward decentralized collective bargaining. They complained bitterly of heightened international competitive pressures and the resulting need for lower labor costs and wider skill differentials, and they argued that decentralized bargaining would help them respond to these pressures by giving them more flexibility and bargaining leverage. Many small employers were less eager to decentralize bargaining, apparently fearing that it would strengthen union power by giving unions the capability to whipsaw employers and in other ways introduce greater instability in industrial relations. In Sweden, as in most of the other countries analyzed in this paper, the central unions have sought to retain centralized bargaining. ${ }^{4}$

\section{Australia}

Australia also traditionally has had relatively centralized collective bargainıng, but of a very different complexion from that in Sweden. The Australian collective bargaining system is noteworthy for its heavy reliance on "industrial tribunals" and a compulsory arbitration system that operates at the federal level and in four of six states (Dabscheck and Niland 1981:305-7). In this system wage minima (and sometimes wage increases) were set in the national and industry "awards" issued by the industrial tribunals. Industryand in some cases firm-level bargaining traditionally provided supplements to these awards ("overawards"), devised the specific terms by which these wage awards were implemented, and negotiated other employment conditions. The Australian industrial relations system also has been noteworthy for a relatively high presence of craft- or occupation-based unions, a union structure that influenced both the wage award system and the supple-

\footnotetext{
${ }^{4}$ The material in this paragraph draws heavily from Pontusson and Swenson (1992) and EIRR (1992a)
} 
mentary industry- and firm-level collective bargaining.

Given the traditional heavy reliance on tribunals and compulsory arbitration, it is fitting that more decentralized collective bargaining has been spurred in recent years in Australia by national wage cases (cases determining wages or wage increases for all workers covered by federal awards) and the decisions in these cases issued by the Australian Industrial Relations Commission. In August 1988, a national wage case decision instituted a "structural efficiency principle," encouraging lower-level negotiations to modify wage awards so as to "improve economic efficiency and provide workers with access to more varied, fulfilling and better paid jobs" (cited in Rimmer and Verevis 1990:1). In the 1988 national wage case decision the Commission stated that the goal of lower-level bargaining and the restructuring of awards was to "establish skill related career paths; eliminate impediments to multiskillıng; create approprıate relativitıes within the award and at the enterprise; ensure that working patterns and arrangements enhance flexibility and efficiency; include properly fixed 'minimum rates' for award classifications; [and] address any discriminatory provisions contained within the awards" (cited in Rimmer and Verevis 1990:1).

That decision was followed in 1989 by a national wage case decision requiring "award restructuring" involving negotiations at the industry or firm level (or both) that may include productivity bargains, issues related to the implementation of wage changes, and associated changes in work rules and work practices. Award restructuring at the Ford Motor Company, for example, involved reductions in the number of job classifications, encouragement of teamwork, and employee involvement in the development of training programs (Lansburg 1993:12-13).

A 1991 national wage case decision explicitly promoted "enterprise bargaining" (bargaining at the firm level, plant level, or both). A 1992 national wage case decision further encouraged enterprise bargaining, and amendments to the Industrial Relations Act in 1992 reduced the Industrial Relations Commission's role in reviewing en- terprise agreements (Lansbury 1993:12).

In Australia, as in Sweden, the engineering sector (which included the automobile manufacturers) pressed for more decentralized bargaining (Macken 1989:33-42). Up through the early $1970 \mathrm{~s}$, collective bargaining covering the auto companies was coordinated across companies by a strong employer federation and a body representung the unions that had members in the industry. In the late 1970 s, however, the large auto firms began negotiating separate company agreements that included a substantial degree of variation in pay and other employment terms across the companies. In recent years a number of important plant-level agreements were negotiated, and some of these agreements included pay-for-knowledge procedures and other new pay administration features. Company-level agreements have now also spread to many of the smaller firms involved in auto parts manufacturing. ${ }^{5}$

The effect of these wage decisions and other economic pressures has been to increase the extent of collective bargaining at the industry, firm, and plant levels. Some of this decentralized bargaining has followed as part of labor and management's efforts to satisfy the specific requirements of the industrial relations commission concerning structural efficiency and award restructuring. The extent of firm- and plant-level bargaining varies widely, and there is disagreement in the academic community over whether they are only a recent phenomenon. ${ }^{6}$ At the same time, there is widespread agreement that there is a trend toward decentralization. This recognition has spurred a debate in the Australian industrial relations community regarding the advantages of "managed decentralism" versus either retention of the old tribunalarbitration system or a more comprehensive

\footnotetext{
${ }^{5}$ I benefited greatly from input from Russell Lansbury and Mark Bray, who helped clarıfy Australıan events They bear no responsibility, of course, for my interpretation of these events

${ }^{6}$ Even with recent changes, workplace bargaining still is rather limited The 1989-90 workplace survey states that "at one-third of workplaces, bargaining took place between management and delegates from the union covering most employees" (Callus, Morehead, Cully, and Buchanan 1991 14)
} 
shift to "enterprise bargaining" (Lansbury and Niland 1992; Bray 1991).

In contrast to the experience in the other countries reviewed in this paper, in Australia the central union federation (the Australian Confederation of Trade Unions, ACTU) has supported decentralization. ${ }^{7}$ As Bray (1991) notes, the ACTU "favored a decentralization of bargaining towards the enterprise level provided this occurred within a strong centralized framework (at national and industry levels)." The ACTU's support for decentralization derived from (and the labor movement said it was contingent on) the continuation of the "Accord," an incomes policy involving the Australian federal government and the labor movement. The Accord initially "envisaged federal government support for full wage indexation in return for the unions pledging to make 'no extra claims' for wage increases" (Lansbury and Niland 1992:2). Full wage indexation meant that wages rose as much as the cost of living. The Accord continues (it is now in a seventh phase), but it no longer provides for full wage indexation.

There are also frequent reports of shop floor and plant-level negotiations that involve significant changes in work organization. Some of the cited cases involve the introduction of team systems of work and large reductions in the number of job classifications. At some sites team work is associated with the introduction of pay-for-knowledge schemes and more extensive worker participation (Mathews 1989).

It is noteworthy that the trend in union structure in Australia runs somewhat counter to the decentralization occurring in bargaining structure. In Australia, as (we shall see) in the United Kıngdom, recently there has been significant consolidation in union structure, involving the merger of craft- or occupationbased unions into either multi-skill or, in some cases, industrywide unions. For the unions, consolidation is attractive partly because of the advantages coordination pro-

\footnotetext{
${ }^{7}$ See, for example, Sword (1992) for the views on enterprise bargaining of the National Secretary of the Natıonal Union of Workers
}

vides during industry- or firm-level bargaining (Rimmer and Verevis 1990).

\section{Germany}

The collective bargaining structure in Germany (by which, in this paper, I mean the former West Germany) involves master labor agreements that are negotiated regionally and cover industrial sectors. Union participation in this process is coordinated by central unions, the most important being the 16 national unions covering industrial sectors affiliated with the Deutscher Gewerkschaftsbund (DGB) (Turner 1991:96-97). The negotiated agreements cover wage increases and provide either specific or "framework" language concerning other employment terms.

Informal bargaining at the company and plant level sometimes occurs. In the 1970s (and for some firms later) this supplementary bargaining ("second rounds") produced sizable wage drift (Thelen 1991). At the plant level unions can use their influence on works councils to veto overtime and in other ways exercise bargaining leverage against management (Streeck 1984a; Thelen 1991; Turner 1992). Yet, company- or plant-level bargaining in Germany does not lead to contractual agreements, nor can unions legally initiate strikes over disagreements arising in this supplementary bargaining.

Another key feature of the German industrial relations system is the parallel representation workers receive through codetermination procedures providing elected representatives with seats on firm supervisory boards and works councils. The works councils address personnel matters, and in this way they provide plant- and firm-level forums for negotiation over matters that in some other countries are addressed in local collective bargaining agreements (Streeck 1984a). ${ }^{8}$

\footnotetext{
${ }^{8} \mathrm{By}$ federal law, the works councils are not allowed to strike over disputes reached in their discussions. It should also be noted that union membership and works council membership are not always mutually exclusive, individuals active in or loyal to unions in many firms hold a sizable fraction of the works council worker seats (Streeck 1984a; Turner 1991)
} 
In contrast to the experience in the other five countries examined here, no change in the formal structure of bargaining has occurred in Germany in recent years. The structure described above continues to prevail. On the other hand, a number of analysts have observed a significant shift toward decentralization in the importance and amount of negotiations that occur inside the works councils at the plant level. Workshop discussions concerning the implementation of changes in work practices have also increased. As Thelen (1991:155) describes it, "The balance within the dual system is shifting toward plantlevel bargaining." In an insightful early analysis, Streeck (1984b:306) identified (and forecast the intensification of) centrifugal tendencies in the German industrial relations system signaling "emergent enterprise unionism." Streeck and others claim that "qualitative demands" have increased in their importance and that these demands are being settled through "productivity coalitions" being formed at the plant or work group level, which often involve works councils (Windolf 1989; Turner 1991; Thelen 1991).

As in other countries, in Germany the productivity coalitions being negotiated at the plant and workshop level typically involve changes in work organization and team work. In some cases the discussions are so comprehensive that they allow the works council to become, as Streeck (1984b:308) put it, the "co-manager of the internal labor market." Turner's (1991) analysis of recent labor-management relations in the German auto industry provides numerous illustrations of the depth of works council penetration into personnel and work organization matters. These negotiations include topics such as the consequences for workers of the introduction of new technology, the adjustments policies introduced to respond to displacement, and the form and procedures through which teamwork is introduced.

The central union (in the auto industry it is I G Metall) is often heavily involved in stimulating and guiding the firm- and plantlevel negotiations. Turner (1991:111-17) describes, for example, how I G Metall formulated and then promoted specific proposals for "group work." Nevertheless, works councils are being granted greater authority in the implementation of group work, the modification of other employment terms, and the negotiations surrounding these issues.

Although the formal structure of collective bargaining has not changed, a more decentralized bargaining structure has resulted from changes in the sectoral collective bargaining agreements. On certain key issues, those agreements no longer provide either specific stipulations or binding minima; rather, they define parameters for plant-level bargaining.

The reduction of working hours after 1984, well described in Thelen (1991:161-75), illustrates how this change has occurred. The sectoral agreements (first those negotiated by I G Metall) defined specific target dates for reductions in work time. These sectoral agreements, however, only provided guidelines for subsequent plant-level negotiations concerning the exact terms and form of the work hours reduction. The sectoral agreements allowed for an uneven distribution of work-time reduction across the work force and gave employers the freedom to vary work hours from week to week (Thelen 1991:165). Furthermore, as Thelen documents, wide variation followed across firms and plants in how the work time reductions occurred and in related changes made to work organization to facilitate the new work time arrangements. In the process, sectoral agreements, although still a critical influence on wage increases, became less influential with regard to the many non-wage issues that surfaced at the plant level.

There are also recent signs of dissatisfaction within employer ranks with the traditional heavy role played by industry bargaining. Medıum and small employers, in particular, have been complaining that "the rigidity and uniformity of existing structures are undermining their flexibility and ability to compete" (EIRR 1992b:12).

\section{Italy}

Collective bargaining in Italy occurs at numerous, frequently overlapping levels (EIRR 1992c). The traditional centerpiece of Italian collective bargaining was a set of 
master industrywide agreements negotiated by national industry unions and employer associations. ${ }^{9}$ Negotiations by union locals at individual firms followed shortly thereafter, providing language and details implementing the terms agreed to in the national contracts (Locke 1992; Locke, forthcoming, 183). In the 1980 s this pattern was modified as the importance of the national industrywide contracts declined. In some industries, national industry con tracts either were not developed or were not implemented. In some other cases, the industry contracts were negotiated after a number of local agreements were reached and followed the terms agreed to in these local contracts (Locke, forthcoming; Windolf 1989; Regalia and Regini 1992). By 1991, there were even discussions within several unions about formally ending national industrywide contracts and replacing them with sub-sectoral or regional contracts (Locke, forthcoming, 214).

Very much as in other countries, company- and plant-level agreements were becoming more important in Italy by the late 1980 s. By $1990,38 \%$ of companies concluded a company- or plant-level agreement (EIRR 1992c). The rise in the importance of local bargaining is illustrated by bargaining at Intersind/ASAP covering state holding companies, including companies in the petrochemical and telecommunications industries. The 1991 national agreement covering the Intersind/ASAP state sector defines all basic conditions of employment, including basic pay rates, information and trade union rights, job classification systems, working time, and the designation of subjects that are to be bargained over at the enterprise level. Enterprise bargaining deals with working arrangements and schedules, work organization, technological innovation, plant relocations, ap-

\footnotetext{
${ }^{9}$ These industrywide agreements were negotiated by the three "peak" trade unions in Italy, the CGIL, CISL, and UIL. In a particular year's bargainıng round, a leadıng firm was targeted by the unions, and after an agreement was reached at this firm, the national industry contract was formed through the diffusion of this agreement, with only minor modification, to the rest of the industry These contracts were negotiated every three years, and renewal was often automatuc (Locke, forthcoming, 182-83)
}

plication of the job classification system, and other local matters. With regard to pay, only increases related to productivity can be bargained at the enterprise level (EIRR 1992c:21). In the past, enterprise bargaining in Italy was much more limited and informal (Locke 1992).

As in Germany, the reduction and regulation of work time in Italy had replaced wages as the central issue in collective bargaining negotiations by the late 1980 s. Furthermore, in Italy as in other countries, although national-level bargaining addressed work time, the national contracts typically established work hour targets and left decisions concerning how to implement and regulate the new work arrangements to local negotiations. ${ }^{10}$ And as in Germany, discussions concerning work time reductions in Italy often became enveloped in wide-ranging modifications of work rules, employment patterns involving the use of part-time and temporary workers, and work organization.

In addition, at many plants in Italy local unions and managers agreed to extensive changes in work organization and pay procedures as they formed productivity coalitions. There were wide variations in the work organization changes and the degree of conflict in these plant-level negotiations. Furthermore, "there is a growing divergence between bargaining in companies and that at higher levels. At the lower level, there seems to be an increasing common concern tojointly manage industrial relations processes in a manner quite divorced from events at the centralized level" (EIRR 1992c:24).

Although the decline in the importance of national industrywide contracts was widespread in Italy, there was simultaneously some movement upward in the locus of collective bargaining. During the 1980 s there were important "tripartite" agreements negotiated by union confederations, employer associations, and government officials. ${ }^{11}$ The focus

\footnotetext{
${ }^{10}$ See Locke's description of this pattern in the textıle industry (forthcoming, 184-85). Also see Windolf (1989)

${ }^{11}$ The national industry unions provide $50 \%$ of the delegates to the confederal union congresses (Locke, forthcoming, $p$ 231)
} 
in these tripartite agreements was on wage increases; in particular, the key issue in dispute was the role to be played by a cost-ofliving escalator (the scala mobile).

\section{United Kingdom}

In Britain, two types of decentralization occurred in the structure of bargaining during the 1980 s and early 1990 s. One involved a decline in the number of multi-employer agreements. The number of multi-employer agreements had been declining since the 1950 s, but the decline accelerated in the 1980 s as multi-employer agreements were replaced by either single-employer or, in some cases, plant-level contracts (Brown and Walsh 1991). Declines in the amount of multi-employer bargaining from the late 1970s are well documented in the Britss workplace industrial relations surveys (Brown 1981; Daniel and Millward 1983; Millward and Stevens 1986; Marginson et al. 1988; Millward et al. 1992). In fact, those surveys are without parallel in other countries with respect to the level of detail and longitudinal comparability they provide on the structure of bargaining. There is also widespread case analysis of the shift away from multi-employer bargaining. (See, for example, Marginson et al. 1988; IRRR 1989, 1990.) There are no major examples of movements in the opposite direction, from company-level to mult1-employer bargaining.

Multi-employer bargaining has persisted in industries such as textiles, footwear, retailing, and clothing, but even in these cases its role has weakened because its function has often shifted to the setting of only minimum employment terms (Marginson et al. 1988:141). In the industries in which multiemployer bargaining has persisted, employers (with low capital requirements and relatively small scale) feared that company- or plant-level bargaining would strengthen the unions' ability to engage in whipsaw tactics and in other ways bring instability to the process of bargaining (Marginson et al. 1988:141-43). As in other countries, central unions generally opposed the shift away from multi-employer bargaining, and the process proceeded in response to employer mitiatives.
A second decentralizing movement occurred in Britain through the replacement of companywide labor agreements with agreements reached at the plant, division, business unit, or profit center level (Brown and Walsh 1991; IRRR 1989; Marginson et al. 1988; Purcell and Ahlstand 1989). In some companies, the negotiation of pay was decentralized downward while work hours and holıday bargaining continued to be settled in companylevel negotiations (IRRR 1989). Furthermore, there was much variation in the degree to which informal pattern bargaining across plants, for example, continued to produce standardization in employment terms within companies even in the absence of a companywide contract (Marginson et al. 1988:151). In addition, there has been some centralization of bargaining within plants through the weakening of shop stewards and the enhanced professionalization of personnel staffs.

As in Australia, the shift to company-level bargainıng in Britain was in some cases accompanied by the consolidation of union structures. The spread of so-called single table bargaining (in which a single employer bargains jointly with several unions with which it had previously negotiated individually) often involved the joining of unions representing manual and staff unions, as occurred at Lucas Industries (IRRR 1989; Marginson and Sisson 1990).

In addition, for some unionized technical and clerical staffs, an even more extreme form of bargaining decentralization occurred through the introduction of individual labor contracts (IRRR 1989). These employees now had their pay (and in some cases also other employment terms) set through individual contracts rather than through the traditional company-level contracts. Short of the complete removal of union representation, it is difficult to see how bargaining could become any more decentralized than individual contracts.

There are also widespread reports of substantial increases in the intensity and importance of plant- or work group-level bargaining concerning work organization and related issues. Although the use of team work appears to be less extensive in Britain than in 
many other countries, the negotiation of "functional flexibility," new work time arrangements, and more contingent pay methods spread to a number of work sites (Sisson 1992; Marginson et al. 1988). There also is clear evidence of more frequent direct communication between managers and workers.

\section{United States}

As in Britain, in the United States the structure of bargaining affecting unionized employees in the early 1980 s was a mixture of multi-employer, firmwide, and plant-level bargaining. Furthermore, during the 1980s the structure of bargaining in the United States underwent changes that were similar to the types of decentralization under way in the United Kingdom. Multi-employer bargaining in the United States in some cases ended; the basic steel agreement, for example, was abandoned in 1986 . In some other cases, the number of firms and unionized employees covered by a multi-firm agreement declined as some companies withdrew from master agreements. Two examples of this occurrence were in trucking, where the Master Freight Agreement negotiated by the Teamsters and an employers' association set terms for inter-city truck drivers, and in the underground coal mining sector, where the United Mineworkers negotiated a master agreement with the Bituminous Coal Operators Association (Kochan, Katz, and McKersie 1986:128-30; Katz and Kochan 1992:19597).

There were also widespread reports of a shift to the plant level away from companywide agreements. In many cases, such as the auto, tıre, and airline industries, the negotiations that were affected by this change were those on local pay or work rule concessions. Often these negotiations involved whipsawing by management, with local unions and workers being threatened with the prospect of a plant closing if adequate concessions were not granted (Cappelli 1985; Katz 1985:63-71; Kochan, Katz, and McKersie 1986:117-27; Turner 1991:31-90; Parker and Slaughter 1988:74-87). In the winter of 1992, a wellpublicized illustration of this process entailed competition between the local unions at the
Arlington and Willow Run assembly plants in the face of General Motors' threat to close one of the two plants as part of its downsizing. In some other plants, concessions on work rules were accompanied by new arrangements that provided extensive participation by workers and local union officers in decisions that had formerly been made solely by management (Kochan, Katz, and McKersie 1986:146205). In these cases, local bargaining took on the form of the "wildcat cooperation" Streeck (1984) had predicted.

Even where company-level collective bargaining continued, negotiations in the $1980 \mathrm{~s}$ produced diverse agreements across companies that replaced strong pattern bargaining in some industries (which informally had served to centralize bargaining at the multiemployer level). Erickson (1992), for example, documents the emergence of significant inter-company variation in the aerospace industry, and Katz (1985) and Katz and Meltz (1991) describe similar variation across the auto assembly companies. Inter-industry as well as intra-industry pattern bargaining weakened. Budd's (1992) analysis reveals that the influence of a key auto contract settlement had "considerably smaller" effects in 1987-90 than in 1955-79 on the contracts the UAW negotiated in industries other than auto assembly (such as aerospace, auto parts, and agricultural implements). ${ }^{12}$

Testing the effects of bargaining structure on wage outcomes, Erickson (1990) found that the positive returns formal centralized bargaining and pattern-following exerted on manufacturing wages from 1959 to 1978 substantially weakened from 1979 to 1984 . In Erickson's estimated equations explaining manufacturing wage determination, the coefficients on all the institutional measures of centralızed bargaining (except industrywide pattern bargaining) go to zero in the later period.

The American research literature has numerous accounts of bargaining at the plant and work-group level that involve the sort of productivity coalitions that appeared in other

\footnotetext{
${ }^{12}$ Ready (1990) claims that pattern bargainıng had not dechned as of 1983 .
} 
countries. Furthermore, as in other countries, these negotiations typically involved work organization, team systems, pay-forknowledge and other contingent compensation mechanisms, and changes in work time arrangements (Kochan, Katz, and McKersie 1986:146-205; Cutcher-Gershenfeld 1991; Arthur 1992). ${ }^{13}$ Agrowing literature (reviewed in Katz and Keefe 1992) examines the effects of changes in work organization on plantlevel economic performance. ${ }^{14}$ There are also widespread reports of more direct communication between managers and workers in the union sector in the United States that are very similar to developments in Britain and other countries (Eaton and Voos 1992; Kochan, Katz, and McKersie 1986:132-34).

\section{Similarities in Trends Across the Six Countries}

There are many similarities in the changes under way in bargaining structure across the six countries. In all countries, the intensity of local bargaining, whether it involved local unions, work groups, or works councils, increased substantially in recent years. Much of this bargaining involved qualitative issues concerning work organization and work restructuring. In some cases this local bargaining concerned pay increases, and in many countries contingent pay methods surfaced as an issue in local bargaining. In all countries except Germany, there has been a downward shift in the formal structure of bargaining and a consequent reduction in the frequency of multi-employer bargaining. Whether or not company-level bargaining persisted, the frequency and importance of plant-level bargaining rose widely.

Except for Australia (which had special circumstances because of the presence of an accord between unions and the government), the downward shift in bargaining structure

\footnotetext{
${ }^{13}$ The work time negotiations in the United States, in contrast to those in Germany, do not involve reductions in work hours. Rather, they involve increasing the flexibility of work time by introducing, for example, three-shift operations.

${ }^{14} \mathrm{An}$ interesting example of this line of research is Cutcher-Gershenfeld (1991)
}

came in response to employer initiatives, and central unions were opposed to this shift. Only the employers in industries with small production scales and modest capital requirements preferred to retain centralized bargaining structures. Furthermore, even in Germany, where multi-employer bargaining persisted, its influence declined as these agreements provided minimum employment terms rather than, as in the past, contractual standards.

Although decentralization is documented in many case studies and descriptive accounts, there is very little quantitative survey evidence providing longitudinal measures of bargaining structure. The best available evidence of this sort, from the three British workplace surveys, is consistent with the case evidence reported in Britain and with the changes noted in other countries discussed in this paper. Across the six countries there was not a single major industry in which collective bargaining moved from the plant level to the industry or multi-employer level.

Although union membership decline is not the subject of this paper, 1 is important to keep in mind that deunionization represents an extreme form (perhaps the ultimate form) of bargaining structure decentralization. As unionization declines, fewer workers are covered by any sort of labor contract. Unorganized employees have their employment conditions determined either exclusively by employers and the market or through individual (formal or informal) bargains. Across the six countries included in this review, post- 1980 trends in union density varied: union density declined substantially in the United States, Italy, and the United Kingdom, declined less severely in Australia, held steady in Germany, and rose in Sweden (Blanchflower and Freeman 1992, Table 1). Thus, although unionization trends are mixed, if deunionization is counted as a form of decentralization and is added to all the other evidence reviewed above, the movement downward in bargainıng across the six countries is quite spectacular.

\section{Why Is Bargaining Structure Decentralizing?}

In this section I examine the hypotheses that have been offered most frequently to 
explain why the structure of collective bargaining has been decentralizing in recent years. The three leading hypotheses are that decentralization results from shifts in bargaining power, the spread of new work organization that puts a premium on flexibility and employee participation, and a decentralization of corporate structure and diversification of worker preferences. For each of the first two explanations there is a version of the hypothesis suggesting that the decentralization will be short-lived, and another predicting that it will be long lasting. I first describe each of the hypotheses and then evaluate the evidence. Examination of these hypotheses is valuable, in part because understanding the cause of decentralization helps clarify the potential effects of the changes under way in bargaıning structure.

\section{Shifts in Bargaining Power}

One explanation for bargaining structure decentralization is that it results from an increase in management's power. In this vein, bargaining structure is viewed both as a reflection of the parties' relative power and as a determinant of power. As Windmuller (1987:86) noted in describing labor and management's preferences for bargaining structure in various countries, "In so far as preferences do exist, they are predominantly the outcome of assessments by the parties of how their interests-that is, their relative bargaining power-will best be served."

Recent bargaining structure decentralization can be interpreted as a reversal of unions' previous success in using centralized bargaining to take wages out of competition. As employers acquired more bargaining leverage, a change itself caused by intensified international competition and declines in union membership and political strength, they pushed to decentralize the structure of bargaining with the expectation that this change would produce bargaining outcomes more favorable to management.

Management need not be using more decentralized bargaining solely to win lower wage settlements at the bargaining table for this hypothesis to hold. For example, Pontusson and Swenson (1992) argue that
Swedish employers particularly wished to see a widening of skill differentials and felt unable to gain such a widening in the traditional centralized structure. The main point in this hypothesis is that decentralization is used by employers to achieve more favorable bargaining outcomes and was sought primarily for that purpose. In this account, employers have used the bargaining power advantage they gained from shifts in the economic environment to promote a change in the process of bargaining (decentralization) that enables them to gain advantages at the bargaining table.

A "temporary" variant of this hypothesis sees decentralization as a useful tool through which employers have gained bargaining power advantage. The idea here is that it is the process of decentralization that is most important. Employers seem to benefit most from the ability to play plants (and local unions) off against one another - that is, to whipsaw local unions. Yet, after gaining lower wage outcomes or wider skill differentials through whipsawing, employers may in the future prefer to return to centralized bargaining because of the advantages it provides (stability, predıctability, and economies of scale).

In this "temporary" account, employers need decentralized bargaining to gain the concessions they desire because central unions are unwilling to grant them, whereas local unions are more willing to do so. How do we explain central unions' unwillingness to lower labor costs or widen skill differentials if that unwillingness causes employers to try to whipsaw local unions? This question needs to be addressed, particularly in light of the fact that central unions have a strong interest in preserving the key role they play in centralized bargaining. Potential explanations for central unions' recalcitrance are that they have a sluggish perception of the need for change or a lack of sensitivity to changing economic circumstances or to the threat of unemployment.

It is also possible to view decentralization as a product of the decline of the bargaining power held by both management and unions (that is, a decline in the absolute level of power) and not as a product of the relative 
decline of labor's power. This explanation extends the argument contained in previous quantitative analyses of the determinants of bargaining power (Hendricks and Kahn 1982; Deaton and Beaumont 1980; Greenberg 1967). These analyses find that in earlier periods, among multiplant firms with singlefirm agreements, collective bargaining tended to be more centralized the more concentrated the industry (since more concentrated industries have greater economic rents to be shared)..$^{15}$ Following this logic, recent increases in economic competition and international trade have reduced the economic rents available to labor and management and thereby spurred decentralization in bargaining structures.

\section{Productivity Coalitions Focused Around Changes in Work Organization}

A second explanation claims that it is the rise in the importance of work organization and shop floor issues that has led to decentralization in collective bargaining. As Streeck (1984) noted, economic pressures and more flexible technologies have led labor and management to restructure the workplace. At some sites these negotiations have proceeded to the point that local unions and workers have become "co-managers of the internal labor market." As a result of these pressures, non-wage issues have been elevated in importance, and negotiation of these "qualitative" issues is contributing to decentralization. Thorough documentation of the existence of shop floor bargaining over work restructuring is found in a wide range of recent industrial relations research, including Turner (1991), Thelen (1991), Locke (forthcoming), and Mathews (1989).

Although the intensity of plant- and work group-level negotiations over work restructuring is apparent, it is less clear exactly why negotiations over work restructuring and qualitative issues are occurring at local rather than central levels. What is it about these

\footnotetext{
${ }^{15}$ Another finding of these statistical analyses was that multi-firm agreements were more common in industries with low degrees of concentration
}

issues, their implementation, or the process through which labor and management are settling disputes concerning these matters, that has led to intensified local bargaining?

Decentralization may follow from local bargaining because the identification of innovations and the implementation of new forms of work organization require direct participation by workers and local union officials. A central union, for example, cannot come up with a new method of team work that is negotiated centrally with management and then applied across local work sites, because the process of identifying an efficient (or acceptable) team work system and implementing it requires the active participation of local actors.

A related claim is that the new work organization involves changes in a variety of employment practices, including team work, performance-based pay methods, participatory programs, extensive training, and, in some cases, employment security (Katz and Kochan 1992:331-41). Thus, what the parties at the local level are doing is discovering, and then implementing, new packages of employment policies. Furthermore, there are many different appropriate new packages of employment practices that make the central negotiation of these matters impractical and inefficient. As a result, it is not possible for central negotiations to develop new practices and then enforce standardized local adoption of those practices. This explanation for decentralization assumes that the new work organization involves an honest dose of worker involvement, and it implicitly disagrees with critics of "joint processes," who assert that participation is largely a ruse or a device to co-opt workers and unions. ${ }^{16}$

There is also a "temporary" version of the work organization account of bargaining decentralization. In this view, the intensified local bargainıng over work restructuring is a product of the parties' struggles to identify new practices that work well. In effect, local bargaining has followed from a process of expenmentatzon through which labor and man-

\footnotetext{
${ }^{16}$ For critıcism of worker particıpation and joint activities, see Parker and Slaughter (1988)
} 
agement are searching for effective new practices. Bargaining is occurring locally so as to provide a range of experimentation and diversity, because centralized negotiations would be too sluggish and too limited. This sort of local experimentation, however, may well only be a temporary phenomenon that will recede once labor and management have identified successful new work practices. Under this scenario, local bargainıng was necessary only as a learning process, and central unions and employer groups may eventually become the negotiators of qualitative issues once they have learned from their more innovative local branches.

There is little if any evidence suggesting that, as predicted in the "temporary experimentation" explanation for decentralization, the negotiation of work restructuring has begun to shift upward after local parties have identified successful strategies. As discussed below, there is evidence that central unions were inttially caught off guard by the decentralızation of bargaining, and in many countries they appear to have lost control over this process. In some of these countries central unions have begun to define a coordinating role for themselves, but this has not amounted to an upward shift in the negotiation of work restructuring. Thus, there appears to be a high degree of permanence in the local negotiation of work reorganization.

\section{Diversification of Corporate Structure or Worker Interests}

Another explanation for the decentralization of bargaining structure focuses on increased diversification of both corporate structure and worker interests. On the corporate side, this explanation views decentralized bargaining as a product of corporations' decentralization of their internal organizational structure, which has increased the independence of business units or profit centers. Bargaining decentralization is seen as a natural consequence of a process in which more direct responsibility for industrial relations is being passed to lower-level managers in the decentralized corporation (Purcell and Ahlstand 1989; Marginson et al. 1988:183; Lansbury and Niland 1992:13;
Kochan, Katz, and McKersie 1986:62-65).

The push for corporate diversification and decentralization itself is said to be a product of such economic pressures as volatility and uncertainty in the economic environment, the shift from mass to specialized product markets, and increased variation in economic pressures across business lines. These economic pressures combine to put a greater premium on flexibility as the corporation searches for ways to more quickly respond to rapidly changing and competitive environments (Piore and Sabel 1984).

Consideration of the "corporate structural decentralization" explanation calls for a return to the basic question of the appropriate degree of centralization of industrial relations functions inside the corporation. A longstanding literature that bears on that question is the research on corporate strategy and structure (Chandler 1962). The most extensive literature discussing corporate structure as an explanation for recent bargaining decentralization appears in the United Kingdom. Purcell and Ahlstand (1989:406) find, for example, that corporate diversification spurs decentralization of the industrial relations staff function. ${ }^{17}$

One in triguing finding of British researchers is that multinational corporations are less likely than other corporations to engage in multi-employer bargaining (Marginson et al. 1988:27). This tendency may result from the multinational firm's desire to pursue corporate objectives and not respond to the specific economic (or industrial relations) pressures in the countries in which they are engaged in either production or sales. The increasing prevalence of multınational trade and multinational firms may thus help explain the declines in multi-employer bargaining that have occurred in a number of countries. Furthermore, multinational firms' progressive rationalization of their production processes (centralizing production in one country while selling products in many) may

\footnotetext{
${ }^{17} \mathrm{~A}$ number of other researchers analyze the influence of corporate structure See, for example, Marginson et al (1988 184) and Brown and Walsh (1991)
} 
have intensified their interest in centralizing corporate control over industrial relations and increased their desire to avoid multiemployer bargaining. ${ }^{18}$ These factors do not explain, however, why collective bargaining in recent years has become more decentralized even within multinational firms (as well as within domestic firms).

A widening diversity in worker interests (or erosion of worker solidarity) can explain bargaining structure decentralization in a manner that parallels the corporate diversification argument. ${ }^{19}$ The claim in this case is that workers have become less willing to join together to pursue common objectives or sacrifice their own personal gain for the benefit of other workers. This change of heart implies a decline in the appeal of centralized bargaining structures producing standardized labor contract terms. The rivalry between public and private sector workers (and unions) in Sweden, and the deleterious effects this rivalry has had on centralized bargaining there, fits this explanation. One could also point to the increased demographic diversity of the work force to argue that this factor plays a widespread role.

\section{Evaluation of the Evidence and the Three Hypotheses}

Evidence in support of the hypothesis that increased management power has led to decentralization is that management has characteristically pushed aggressively for decentralized bargaining while central unions have opposed it. Also supporting this hypothesis is the fact that in many cases decentralized bargaining has been associated with the negotiation of pay and work rule concessions at the plant level. Such concessions are commonplace in the United States and have been noted in many other countries. Erickson's statıstical analysis, discussed above, also lends credence to this hypothesis by finding evidence that centralized bargaining previously had a positive effect on union wages in the United States. Although the above evidence

\footnotetext{
${ }^{18}$ I am grateful to Jan Katz for suggestıng this point

${ }^{19} \mathrm{I}$ am grateful to Peter Doeringer for suggesting this point
}

1s supportive of the power hypothesis, to date there have been no clear empirical tests of this hypothesis.

My reading of the qualitative evidence suggests that both the long and temporary versions of the bargaining power hypothesis have some credibility. Unions clearly have been on the defensive in many countries, particularly in countries such as the United States and United Kingdom, and the decline in union bargaining power appears to have contributed to their inability to resist employer efforts to decentralize bargaining. At the same time, the increase in managements' power does not appear to fully explain recent events. For one thing, it is not obvous that traditional centralized bargaining was so advantageous to unions (and disadvantageous to employers) in the first place. As Weber (1961) and others have noted, centralized bargaining was useful to some employers as a mechanism for avoiding union whipsawing. The most extreme traditional case of bargaining structure centralization, Sweden, can be viewed as an illustration of the wage moderation and stability produced by bargaining structure centralization. And if centralized bargaining did not favor unions, it is not clear why employers would seek to eliminate it now that they have more bargaining power.

Another problem with the bargaining power hypothesis is the fact that local unions and workers often have supported the decentralization of collective bargaining. It is conceivable that local unions, trapped in a fight for survival, agree to decentralization simply as part of a package of concessions in return for keeping their own plant in business. Yet, the case study accounts (discussed above) of the productivity coalitions that are formed in the now widespread local bargaining suggest that survival is not the only incentive. Local union leaders as well as workers at many sites appear to enjoy the participation in shop floor and strategic business decisions they have gained, and they also benefit from some of the more flexible work schedules that have been negotiated. If local unions and workers are realizing gains through local bargaining, an implication is that decentralization does not result only from shifts in power.

In addition, it is hard to see how the union 
weakness argument can be applied to the case of Germany. There, local bargaining increased in importance and scope even though union representation held steady and unions made gains in wage and work hours bargaining in the 1980s. The bargaining structure decentralization under way in Germany hardly appears to be a product of weak unions.

My reading of the evidence suggests, consistent with the second decentralization hypothesis, that both labor and management gain clear advantages from the work restructuring that is under way in many workplaces. More local bargaining seems to be a natural product of the increase in worker and union participation in enterprise and shop floor decision making. It also appears that local bargaining is essential for the identification and implementation of new more flexible forms of work organization. Thus, I am led to the view that work reorganization has played a significant role as a cause of bargaining structure decentralization.

Although decentralization in corporate structure and diversity in worker preferences may also have played a role in spurring bargaining structure decentralization, as predicted by the third decentralization hypothesis, there is little evidence that these factors are widespread enough to explain the extensive decentralization in bargaining that has occurred. Furthermore, although the literature on corporate decentralization and diversification is extremely informative, it is difficult to tell if the bargaining decentralization that researchers are attributing to corporate decentralization is in fact a product of the factors associated with the other two decentralization hypotheses discussed above.

\section{The Changing Roles of Central Unions and Corporate Industrial Relations Staffs}

\section{Central Union Roles}

Although the actions taken by labor and management in response to pressures for decentralization may not be the initial cause of bargaining structure decentralization, these actions may influence both the form and degree of bargaining structure decentralization. Thus, to fully understand how decentralization of bargaining has occurred and what its consequences have been, we need to examine how it has challenged unions' and managements' roles. This analysis also provides an informative illustration of the effects strategic choices can have on the bargaining process and bargaining outcomes.

In all of the countries examined in this paper except Australia, central unions opposed decentralization of bargaining, though in all cases without apparent success. Their opposition seems to derive from the fact that central bodies lose power and, to some extent, their function as the focus of bargaining shifts to the firm or plant level. As power shifts to local unions, they become more difficult to control, and the likelihood of political challenges to central union authority increases. Streeck (1984) and Katz and Sabel (1985) suggested early on that central unions would be hard pressed to define new roles as decentralization proceeded, and experiences in the late 1980 s and early $1990 \mathrm{~s}$ have validated their warnings.

Yet, the evidence from the six countries suggests that unions can influence the nature of bargaining structure and are not just passive recipients of a "decentralization effect." Consider the contrast between events in Germany and Britain. In Britain there has been extensive decentralization in wage setting as well as an increase in the intensity of plantlevel discussion of work organization and flexibility issues, although apparently less of the latter than has been occurring in Germany and a number of the other countries. German unions, meanwhile, have avoided any decentralization in wage setting and any other change in the formal structure of collective bargaining. At the same time, there has been an intensification of negotiations inside works councils and on the shop floor concerning work reorganization in Germany.

It may be that the pressure on unions to cut wages was greater in Britain's economic and political environment than in Germany's. Another driving force, however, may have been the initiative taken by German central unions to develop a role whereby they provided substantial coordination and guidance to local efforts to respond to economic pressures. 
Turner (1991) and Thelen (1991) describe how I G Metall, in particular, maintained a strong role in recent bargaining, with strong unıon membershıp and substantial political influence. During the 1980 s, I G Metall promoted group work schemes and helped guide and structure the changes being made at the plant level in the introduction of these plans (Turner 1991:111-17). And as discussed earlier, although work time reductions were implemented with much variation and input from works councils, this process followed guidelines and parameters contained in contract language centrally negotiated by I G Metall and employers.

British central trade unions were less successful than their German counterparts at defining a new role as the coordinator of local initiatives. Two effects of this weakness may have been greater decentralization of wage negotiations than would otherwise have occurred and, since local unıons and workers received little or no policy guidance from their central unions, less extensive work reorganization on the shop floor. The challenge confronting central unions in this era of bargaining decentralization is to develop an expanded coordinating role-in effect, to create a modern version of the "connective bargaining" earlier described by Ulman (1974)..$^{20}$

It is noteworthy that even German unions have had troubles redefining their role in the face of the growing influence of works councils. Thelen (1991) and Katz and Sabel (1985) suggest that one explanation for I G Metall's forceful campaign for work hours reductions in the mid-and late 1980s was that the central officers in the union were searching for a way to regain the initiative in the face of the increasing involvement of works councils in local bargaining. Work hours was a relatively traditional subject, and one that the central offices of I G Metall knew how to bargain

\footnotetext{
${ }^{20}$ In connective bargamıng, as described by Ulman (1974), the central (often national) union is involved in local union affairs through its involvement in the administration of grievances (for instance, deciding whether a grievance can go to arbitration) and in the approval of local union strike actions (for instance, by not withholding strike funds)
}

over. Meanwhile, I G Metall's membershıp was still growing, and the union was able in the 1980 s to negotiate wage gains and avoid the sort of concessions typically granted in this period by most other unions in other countries. Thus, the problems created by decentralized bargaining for the central offices of I G Metall should serve as an indication of the extent to which much less secure unions in other countries may have been troubled by these events.

The research also suggests that some unions take time to find their new roles in the face of intensified local bargaining. For example, Locke (1992 and forthcoming) argues that central unions in Italy learned from their failures at Fiat in the early 1980 s, and by the tıme local bargaining was intensifying at Alfa Romeo, the central unions had more clearly figured out how they could positively guide events rather than be pushed to the sidelines. In the United States there also has been wide variation in the character and intensity of central unions' responses to the increase in local bargaining (Katz 1988).

\section{The Corporate Industrial Relations Function}

Corporate industrial relations staffs also face major changes in their roles as a result of the decentralization of collective bargaining. The shift in influence from corporate to plant or division industrial relations staffs (Storey 1992; IRRR 1989; Kochan, Katz, and McKersie 1986:197-201) has had pluses and minuses for local industrial relations managers. Although the power of these local staffs rises as they acquire more direct responsibility for bargaining, that responsibility is generally accompanied by greater financial pressures than they experienced before; in some cases they become subject for the first time to explicit cost controls (IRRR 1990; Marginson et al. 1988:183). The redistribution of the responsibility for bargaining has, however, been variable. Even where the formal structure of bargaining has shifted to plant or business unit levels, corporate staffs may continue to set guidelines or exercise informal influence on the negotiations occurring at local levels (Sisson 1992; Marginson et al. 1988:151). 
In addition, managerial industrial relations staffs at several levels have seen their influence decline as more direct authority and responsibility for industrial relations (and human resource) issues has been shifting to operating and line managers (Kochan, Katz, and McKersie 1986:131-32). Storey, for example, provides evidence in Britain of "a more active role for line and general managers in setting the direction of human resource policy" (1992:202). ${ }^{21}$

Corporate industrial relations managers face many problems that parallel those confronting central union staffs. As bargaining began shifting to local levels and focusing more on qualitative issues concerning work restructuring, corporate staffs were initially caught off-guard by the diminution of their influence. These corporate managers (like central unions) are searching to find new roles for themselves through which they can provide guidance in local bargaining and help coordinate local initıatives. One example of a matter on which their guidance may one day be needed is whipsawing by unions. Although the economic climate at present gives employers the whipsaw advantage, over the long term there are likely to be cases in which aggressive unions can use the decentralization of bargainıng to whipsaw employers. Central staffs, as well as local management staffs, will have to find ways to respond to such challenges without the assistance provided formerly through central bargaining structures and the standardization of employment conditions that typically followed from this centralization.

\section{Research Gaps}

There is much need for more research examining variation across countries in changes under way in bargaining structure. In many ways, the research reviewed in this paper provides only a preliminary analysis of these developments.

It will be interesting to examine, for example, what, if any, effects on bargaining

\footnotetext{
${ }^{21}$ As illustrated in a number of the case examples provided in Storey (1992), these human resource policies include industrial relations policies and issues.
}

structure result from European market integration. ${ }^{22}$ Although the emergence of European-wide works councils may serve to recentralize bargaining structure, steps toward European integration have as yet had few substantive effects on bargaining outcomes or structure.

I have found that although there is widespread case and descriptive evidence of decentralization in bargaining structures, there are very few systematic quantitative data tracing the evolution of bargaining structure. The best longitudinal survey data on bargaining structure are from the British work place surveys; in addition, a useful survey of Australian practices has recently been completed. Survey data from other countries would help clarify the depth of the changes being noted in the many case studies. Longitudinal quantitative data tracking bargaining structure would also help in searching for the determinants of decentralization and measuring the extent to which these factors vary across industries or countries. Of course, the various causal factors may be so closely interrelated that the search for "independent" causation may be in vain.

It is clear that much of the decentralization in collective bargaining was initiated by managers who expected to gain more favorable bargaining outcomes through that change, but there is very little evidence on whether managers gained what they expected. Knowledge of how bargaining structure decentralization has affected bargaining outcomes would be informative in its own right, and it would also help explain why decentralization is occurring.

There is also much more to be learned concerning the long-term consequences of bargaining structure decentralization for central union and corporate industrial relations staff functions. It would be extremely interesting to know, for example, whether (and if so, how) certain unions or managers were able to respond more successfully than others to the role challenges created by bargaining decentralization. Furthermore, more research is needed to clarify how union and

\footnotetext{
${ }^{22}$ Streeck (1991) provides provocative thoughts concerning the effects of European integration on industrial relations and union power
} 
management strategies influenced the nature and extent of bargaining structure decentralization.

Decentralized collective bargaining has focused on different issues across the more advanced economies in the world. For example, key issues in dispute in Germany and the United States have been working time and work organization, respectively. Why this variation in the focus of local bargaining? Is it a product of different economic pressures, or of different local institutions and bargaining histories? Thelen (1992) makes a good start in addressing these issues by emphasizing the role played by national institutional "starting points" and union membership levels, but much remains to be done.

Locke (1992) argues that the decentralization of collective bargaining challenges industrial relations theory as much as it challenges unions and management. He claims that the variation in industrial relations practice resulting from the productivity coalitions emerging at many plants (and the absence of such coalitions in other firms and plants) leads to the end of distinctive national systems of industrial relations. Does it make sense to speak of a distinctive Italian or German industrial relations system if there is wider variation within each of these countries in industrial relations practices than there is between the practices characteristic of each country? To answer this question and many others requires more extensive research describing the nature and consequences of the decen tralization of collective bargaining.

My assessment of recent evidence suggests that work reorganization plays a particularly important role in stimulating bargaining decentralization. Why it does so, however, and how prior institutions and histories shape the outcomes and process of the resulting local bargaining concerning work reorganization, are unclear. The local bargaining that is associated with work reorganization often involves informal interactions between labor and management. Yet, much of the language and theory developed to explain traditional bargaining structures is oriented toward more formal types of interaction. Thus, understanding the decentralization of bargaining may require the development of new concepts and theory, as well as a downward shift in the focus of research.

\section{REFERENCES}

Arthur, Jeffrey B 1992. "The Link Between Business Strategy and Industrial Relations Systems in American Steel Minimills." Industral and Labor Relations Review, Vol 45, No. 3 (April), pp 488-506

Blanchflower, David, and Richard Freeman. 1992 "Unionism in the US and Other Advanced OECD Countries" Industral Relations, Vol 31, No. 1 (Winter), pp. 56-79.

Bray, Mark 1991 "Australıan Unıons and Economic Restructuring " Unpublished paper, Department of Industrial Relations, University of Sydney

Brown, William A , ed. 1981 The Changing Contours of Bntish Industral Relations A Survey of Manufacturng Industry Oxford Blackwell

Brown, William A, and Janet Walsh 1991 "Pay Determination in Britain in the 1980s The Anatomy of Decentralization " Oxford Review of Economic Policy, Vol 7, No 1, pp 44-59

Budd,John W 1992 "The Determinants and Extent of UAW Pattern Bargaining "Industnal and Labor Relations Revew, Vol 45, No 3 (April), pp 523-39

Callus, Ron, Alıson Morehead, Mark Cully, and John Buchanan 1991 "Industrial Relatıons at Work The Australıan Workplace Industrial Relatıons Survey."
Commonwealth Department of Industrial Relations, Canberra Australian Government Publishing Service

Cappell, Peter 1985 "Competitive Pressures and Labor Relations in the Airline Industry "Industral Relations, Vol 24 (Fall), pp 316-38.

Chandler, Alfred D 1962 Strategy and Structure Cambridge, Mass MIT Press

Commons, John R 1909 "American Shoemakers, 16481895: A Sketch of Industrial Evolution " Quarterly Journal of Economics, Vol 24 (November), pp 39-81 Cutcher-Gershenfeld, Joel 1991 "The Impact on Economic Performance of a Transformation in Workplace Relations "Industrial and Labor Relations Revnew, Vol 44, No 2 (January), pp 241-60

Dabscheck, Braham, and John Niland 1981 Industral Relations in Australa Sydney George Allen and Unwin

Daniel, W W , and N Millward 1983 Workplace Indusinal Relattons in Britain London Heinemann Educational Books

Deaton, D R, and P. B Beaumont 1980. "The Determinants of Bargaining Structure Some Large Scale Survey Evidence for Britain "Britsh Journal of Industral Relations, Vol 18 (July), pp 202-16 
Eaton, Adrienne E, and Paula B Voos 1992 "Unıons and Contemporary Innovations in Work Organızatıons, Compensation, and Employee Participation " In L Mishel and $\mathrm{P}$ Voos, eds., Unions and Economic Competztiveness Washington, D C Economic Policy Institute, pp 173-216

Erickson, Christopher L. 1990 "Union Wage Determınation in Manufacturing in the 1980s Three Empirical Investigations " Ph D. diss , MIT, pp 10-170

1992 "Wage Rule Formation in the Aerospace Industry "Industral and Labor Relations Review, Vol 45, No 3 (April), pp 507-22.

European Industral Relations Revıew 1991 "Debate on Labour Costs " No 205 (February), pp. 27-28 1992a "The Rise and Fall of Centralized Bargaining " No. 220 (April), pp 20-22 $1992 b$ "Revolt of the Mittelstand-Pressures for Bargaining Reform " No 221 (June), pp. 12-14 1992c "Collective Bargaining in 1991 " No 227 (December), pp 20-24

Flanagan, Robert J , David W. Soskıce, and Lloyd Ulman 1983 Uniontsm, Economic Stabultzation, and Income Poltcies European Expenence Washington, DC The Brookings Institution

Greenberg, David H 1967 "The Structure of Collectuve Bargaining and Some of Its Determinants "In Gerald G Somers, ed, Proceedings of the Nineteenth Annual Winter Meeting Madıson, Wis. Industrial Relations Research Association pp 343-53

Hancke, Bob Forthcoming "Trade Unon Membership and Decline in Europe 1960-1990-Rediscovering the Locals "Bntzsh Journal of Industral Relations

Hendricks, Wallace E, and Lawrence M Kahn 1982 "The Determinants of Bargainıng Structure in U S Manufacturing Industries "Industral and Labor Relathons Revew, Vol 35, No 2 (January), pp 181-95

Industral Relatnons Revew and Report 1989 "Decentralized Bargainıng in Practice 1" Report 454 December, pp 5-10

1990 "Decentralızed Bargainıng in Practıce: 2 " Report 457 February, pp. 5-6

Katz, Harry C 1988 "Policy Debates over Work Reorganization in North American Unions" In Richard Hyman and Wolfgang Streeck, eds, New Technology and Industral Relations International Expenences Oxford Basil Blackwell, pp 220-32

Katz, Harry C , and Jeffrey H Keefe 1992 "Collective Bargaining and Industrial Relations Outcomes The Causes and Consequences of Diversity "In D Lewin, $\mathrm{O}$ Mitchell, and $\mathrm{P}$ Sherer, eds, Research Frontiers in Industral Relations and Human Resources Madison, Wis Industrial Relations Research Association, pp 43-76

Katz, Harry C, and Thomas A Kochan 1992 An Introduction to Collectuve Bargainıng and Industral Relations New York McGraw Hill

Katz, Harry C, Thomas A Kochan, and Jeffrey $\mathbf{H}$ Keefe 1987 "Industrial Relations and Productivity in the US Automobile Industry" Brookings Papers on Economic Activity, Vol 3 Washington, D C The Brookings Institution, pp 685-728

Katz, Harry C , and Noah Meltz 1989 "Changing Work Practices and Productivity in the Auto Industry A
U S -Canada Comparison " in Michel Grant, ed, Pro ceedings of the 26 th Conference of the Canadian Industral RelationsAssociation Quebec University of Laval Press, pp 384-96

1991 "Profit Sharıng and Auto Workers' Earn1ngs The United States vs Canada" Relatıons Industrelles, Vol 42, No. 3, pp 513-30.

Katz, Harry C., and Charles F Sabel 1985 "Industrual Relations and Industrial Adjustment in the Car Industry" Industral Relations, Vol 24 (Fall), pp 295-315

Lansbury, Russell D 1993 "Changing Patterns of Industrial Relations and Human Resources in the Australıan Automotive Industry Towards Transformation?" Unpublished paper presented at the meetıng of the International Motor Vehıcle Program, M I T, June 1

Lansbury, Russell, and John Niland 1992. "Recent Trends in Industrial Relations and Human Resource Policy and Practice The Australian Experience" Paper presented at the International IR/HR Project Meetıng, Parıs, June 22-24.

Locke, Richard M 1992 "The Decline of the National Union in Italy Lessons for Comparative Industrial Relations Theory" Indusinal and Labor Relations Reveew, Vol 45, No 2 (January), pp 229-49

Forthcoming Re-building the Economy Local Polntics and Industral Change in Contemporary Italy Ithaca Cornell Unıversity Press

Macken, James J 1989 Award Restructurng Sydney The Federation Press

Marginson, Paul, et al 1988. Beyond the Workplace Managzng Industral Relations in Multz-Establishment Enterprises Oxford Blackwell

Marginson, Paul, and Keith Sisson 1990 "Single-Table Talk " Personnel Management, May, pp 46-49

Mathews, John 1989 Tools of Change New Technology and the Democratization of Work Sydney Pluto Press

Millward, N, and M Stevens 1986 Bntısh Workplace Industnal Relations 1980-1984 Aldershot Gower

Millward, N, et al 1992 Workplace Industral Relations in Transition Brookfield Dartmouth University Press

Parker, Mike, and Jane Slaughter 1988 Choosing Sides Unions and the Team Concept Boston South End Press

Pontusson, Jonas, and Peter Swenson 1992 "Markets, Production, Institutions, and Pohtics Why Swedish Employers Have Abandoned the Swedish Model " Paper presented at the Eighth International Conference of Europeanists, The Council for European Studies, Chicago, March 27-29

Purcell, John, and Bruce Ahlstrand 1989 "Corporate Strategy and the Management of Employee Relatıons in the Multi-divisional Company "Britush Journal of Industral Relatıons, Vol 27, No 3 (November), pp 396-417

Ready, Kathryn J 1990 "Is Pattern Bargainıng Dead" Industral and Labor Relations Revew, Vol 43, No 2 (January), pp 272-79

Regalıa, Ida, and Marıno Regını 1992. "Comparatıve IR/HR Research Network-Italian Report " Paper presented at the International IR/HR Project Meeting, Paris, June 22-24

Rimmer, Malcolm, and Chrissie Verevis, eds 1990 Progress of Award Restructurng Case Studzes Mono- 
graph 28 Kensıngton, NSW, Australıa Industrial Relations Research Centre

Sisson, Keith 1992 "Change and Contınuity in UK Industrial Relations 'Strategic Choice' or 'Muddling Through'?" Paper presented at the International IR/ HR Project Meeting, Parıs, June 22-24

Storey, John 1992 Developments in the Management of Human Resources An Analytıcal Review Oxford Blackwell

Streeck, Wolfgang. 1984a Industrial Relations in West Germany A Case Study of the Car Industry New York St Martin's

1984b "Neo-Corporatıst Industrial Relations and the Economic Crisis in West Germany" In John H Goldthorpe, ed, Order and Confluct in Contemporary Capitalism Oxford Oxford University Press, pp 291314

1991 "More Uncertaintıes German Unıons Facing 1992 "Industral Relations, Vol 30, No 3 (Fall), pp 317-49

Swenson, Peter 1989 Fair Shares Unions, Pay and Polttics in Sweden and West Germany Ithaca, N Y Cornell University Press

Sword, Greg. 1992 “Enterprise Bargains-The Framework" In Michael Croby and Michael Easson, eds , What Should Unions $D o^{2}$ Leichardt, NSW, Australia Pluto Press, pp 257-64

Thelen, Kathleen A 1991 Union of Parts Labor Polatics in
Postwar Germany Ithaca, N.Y: Cornell University Press 1992 "The Changing Character of Industrial Relations in Contemporary Europe." Unpublished paper presented at the workshop, "A New Europe Rethınking the Collectıve Response to Change,"Center for European Studies, Harvard University, Cambridge, Mass, December 11-13

Turner, Lowell 1991. Democracy at Work Changing World Market and the Future of Unions. Ithaca, N Y Cornell University Press

Ulman, Lloyd. 1974 "Connective and Competitive Bargainıng "Scottash Journal of Poltzcal Economy, Vol 21, No. 2 (June), pp 77-109

1955 The Ruse of the National Trade Union Cambridge, Mass. Harvard University Press.

Weber, Arnold B 1961 "Introduction" in Arnold Weber, ed, The Structure of Collective Barganning New York The Free Press, pp xv-xxx11

Williamson, Oliver 1968 "Wage Rates as a Barrier to Entry The Pennıngton Case in Perspective." Quarterly Joumal of Economecs, Vol 82, No 1 (February), pp 85116

Windmuller, John 1987 Collectıve Bargaınıng ın Industralized Market Economies A Reappraisal Geneva: International Labour Office

Windolf, Paul 1989. "Productivity Coalitions and the Future of Corporatusm." Industral Relations, Vol 28 (Winter), pp 1-20. 